\title{
American Democracy and the Problem of Fiscal Deficits
}

\section{Richard E. Wagner}

Harris Professor of Economics, George Mason University

\begin{abstract}
Most theorists of public finance treat budgeting as a technical problem centered on projecting revenues and expenses. In contrast, I treat budgeting as a political problem, with technical matters serving to obscure more than illuminate that problem. This essay starts by explaining why persistent budget deficits have little to do with technical matters because they mostly reflect the conflictual character of contemporary political economy. The rest of the essay probes this conflictual character by providing a conceptual framework grounded in the inherently complex character of fiscal systems, and with this complex character contrasting sharply with the image of simplicity advanced by most theorists of public finance. The key point I advance is that democratic budgeting, especially in large national governments, will more likely operate as a source of turbulence than as a source of systemic stability.
\end{abstract}

Keywords: budgetary process; public debt; parasitical politics; Image creation; non-logical action; emergence vs. axiomatics

JEL Codes: D72, D78, E62, H61, P16

Acknowledgement: I am grateful to Akira Yokoyama and Roger D. Congleton for offering helpful remarks and suggestions on the initial draft of this essay.

\section{Starting with some simple observations about American budgeting}

The historical record of budgetary practice by the American federal government shows two periods with distinct budgetary patterns. In this respect, Buchanan and Wagner (1977) and amplified by Wagner (2012a), American federal budgeting from the founding in 1789 until the Great Depression of the 1930s displayed a tendency to run modest surpluses during normal periods of prosperity, with budget deficits limited to periods of war and depression. Indeed, there were periods where federal public debt practically vanished. From the 1930s until the mid-1940s, the federal government was involved in a depression followed by war, so the public debt that was accumulated during this time seemed to be normal practice.

But the period following 1945 did not see a resumption of budget surpluses to start retiring the debt that had been accumulated. Federal budgetary practice after 1945 through 1960 showed ambiguity when compared against the historical record since 1789 . Those 15 years saw alternating deficits and surpluses, and with public debt changing little in the aggregate. This period saw no concerted effort by the federal government to retire public debt. It was perhaps the observed ambiguity of budgetary practice during this period that led some thinkers to replace the principle that opposed budget deficits as a general procedure with one that 
aimed to achieve a balanced budget over an interval that corresponded with a business cycle.

After 1960, however, it would be impossible to claim that budgetary practice was aimed at cyclically balanced budgets. Budget deficits became universal as they occurred in good times as well as in bad times. It seems apparent that the American federal government experienced a regime change in the period between 1930 and 1960. Buchanan and Wagner (1977) attributed this change to the infusion of Keynesian ideology into budgetary practice, recognizing that budgetary practice is the province of politicians and not economic theorists. Wagner (2012a) affirmed the contours of Buchanan and Wagner (1977) while also noting the complementarity between the Keynesian ideology and the ideology of progressivism that entered the American political economy in the second decade of the $20^{\text {th }}$ century.

The progressivist ideology challenged the foundations of the American constitutional order which was based on a belief that the use of government represented a form of Faustian bargain in that such use entailed an instrument of evil being used because there was some hope that such use would promote more good than the evil that would accompany that use. In this respect, the American constitutional system was grounded on a division of governmental power among different holders of pieces of that power. To the extent governance proceeded, it would require concurrence among various pieces of the power required for governmental activity. This doctrine of the division and separation of powers gave institutional recognition to the Faustian bargain that government inescapably entailed, and as Vincent Ostrom $(1984,1996)$ explains lucidly.

The American opposition to the traditional American constitutional order can be dated from publication of Woodrow Wilson's (1885) Congressional Government, where he castigated the division and separation of powers that the American Constitution established. Where the American Constitution established a polycentric form of government which lacked the apex that a monocentric structure had, Wilson argued in favor of monocentric governance on the ground that rationality in governance would be improved by creating simple and powerful lines of authority. It can reasonably be said that the progressivist orientation has been ascending over the past century, though belief in the virtue of polycentricity and the Faustian character of governmental power remains alive in American society.

The coming of the Keynesian ideology in the 1930s complemented the progressivist ideology that emerged earlier. Where the American republic was founded on polycentric principles that avoided concentrations of power, the progressivist and Keynesian ideologies looked to the concentration of power. Keynes, for instance, remarked in the Foreword to the German translation of his General Theory (Keynes 1936) that "the theory of output as a whole, which is what the following book purports to provide, is much more easily adopted to the conditions of a totalitarian state, than is the theory of production and distribution of a given output produced under conditions of free competition" Garvey (1975: 403). The progressivist ideology supported Keynes's support of concentrated political power by claiming that individuals required guidance by experts because otherwise most individuals were incapable of acting rationally within large fields of action. That ideology construed governance as something like shepherds guiding sheep, for sheep were not capable of managing their af- 
fairs wisely without the controlling guidance of shepherds.

In this respect, Keynes's biographer Roy Harrod (1951: 192-93) notes that Keynes did not believe in the value of democratic governance and, moreover, was relieved that the British government of his time was not genuinely democratic. To the contrary, Harrod explains, Keynes was imbued with what Harrod called "the presuppositions of Harvey Road." Harvey Road was the location of the Keynes family home in Cambridge, and by these presuppositions Harrod meant that Keynes thought that the activities of the British government were controlled by an elite handful of people who governed through discussion and persuasion.

Where the progressivist ideology focused on micro-level issues of governance, the Keynesian ideology brought macro-level questions under the same rubric. Where the classical theory of the macro economy was dominated by Say's Law of Markets which rejected the idea of a general glut across all markets, explaining instead that a deficient demand in some markets had to be offset by an excess demand in other markets. The primary implication of Say's Law was that persistent unemployment could result only because controls prevented price flexibility at places within in the economic system. Price flexibility would not prevent the emergence of unemployment, but it would guarantee the short-lived character of any such unemployment. To be sure, "short-lived" is an abstract and not a substantive concept. The description of being short-lived entails no measure of calendar time, but rather speaks only to a tendency for unemployment to erode with the passing of time. It was in this respect that Keynes noted that in the long run we are all dead. Keynes didn't so much deny the classical wisdom as he was impatient with the counsel it seemed to give.

In other words, Keynes, just like the progressivist micro-thinkers, looked to an activist government to occupy the institutional foreground in promoting economic prosperity. The classical emphasis on market arrangements was not explicitly rejected, in sharp contrast to Marxism with its emphasis on abolishing the alienation of production for markets. Rather, the emphasis on market arrangements was relegated to the societal background, and it became government rather than markets that bore primary responsibility for assuring the common prosperity and general welfare. In this respect, the American federal government created the Employment Act of 1946. This Act institutionalized the Keynesian claims on behalf of ultimate governmental responsibility for the common prosperity.

At this point we come to one of those forks in the road that litter all fields of scholarly discourse. Along one branch of that fork, the progressivist and Keynesian visions would be treated as correct. This is the most prominent set of presuppositions in play within American political economy today. Along the other branch, those presuppositions could be wrong, which in turn would reaffirm the classical vision of political economy. This set of presuppositions is also in play within American political economy, though it holds a minority position. It will also be worthwhile to consider what happens when governance is based in inaccurate presuppositions. In particular, what happens if Keynesian presuppositions are employed despite the correctness of the classical presuppositions? 


\section{Is Rational Democratic Budgeting Impossible?}

How well does democratic budgeting complement economic organization based on free markets? Not much, and decreasingly so as the scale of government increases. All but one American state has some constitutional requirement for a balanced budget but few of them operate this way. In 1979 the federal government enacted a public law, known as Byrd-Grassley and discussed by David Primo (2007), which required it to have balanced its budget by 1982. As Primo explains, this legislation was never repealed but neither has budget balance become the modus operandi of the American federal government. As a technical matter, however, budget balance is easy to achieve, as Miller (1994) explains. But budgeting is political and not technical, and this makes all the difference, as Wagner (2012a) explains. As the scale of government increases, moreover, governments move from being largely consensual to becoming increasingly factional, as Bertrand de Jouvenel (1961) explains crisply. In consequence, budgeting becomes a locus of redistribution, rendering budgeting a source of turbulence and not a source of systemic stability. This situation seems irreparable through the use of democratic voice, provided only that that voice is multi-vocal and not concordant, though it can probably be lived with even if uncomfortably.

The key point of difference between my treatment of turbulence and conventional treatments of fiscal policy operating to promote systemic stability lies in different conceptualizations of how we move from the action level to the systems level. Standard thinking treats the systems level as directly accessible and manipulatable. For example, standard thinking about using fiscal policy to promote systemic stability operates in terms of using government spending to offset changes in private spending within the income-expenditure framework where $\mathrm{Y}=\mathrm{C}+\mathrm{I}+\mathrm{G}$. While contemporary textbooks have deemphasized the income-expenditure model, the near-universal answer to some perceived shortfall in aggregate spending is to call for increased government spending, recognizing that there are different ways a government can increase spending. At the time of Keynes, increased spending resulted from budget deficits financed by treasury debt. These days, increased spending might result from a central bank buying financial assets and calling it quantitative easing. Either action, however, envisions increased government spending as replacing a perceived deficiency in private spending. The theorists have put old wine in new bottles, but it tastes about the same.

In contrast to conventional thinking, thinking in terms of systems entails thinking in terms of discrete levels of phenomena, as Donella Meadows (2008) explains through her exposition of system-based theorizing. System thinking entails a distinction between an action level and a system level. This distinction goes back to the Scottish Enlightenment where the analytical core distinguished between what people could design on the one hand and the emergent products of human action and interaction on the other hand. All action is thus local in nature. The system level is many things, including statistical aggregations and projections, along with reflections of beliefs, hopes, and ideologies. It is not, however, a place where action occurs. Action can be inspired by statistics and projections as well as ideolo- 
gies and beliefs, but all action must manifest at the ground level where transactions occur. Observations that pertain to the system level are generated through interaction among the individual entities that populate and comprise the system. This difference in conceptual orientation creates a different orientation toward fiscal policy, budgetary processes, and the relation between free markets and democratic polities.

\section{Opinion, Power, and Ideology in Democratic Polities}

Adam Smith (1776 [1936] was surely correct when he opined that what comprises wise and prudent budgeting for a nation is the same as for a family. To be sure, this wisdom has been challenged with the advent of the Keynesian theory of fiscal theory that is grounded on an alleged fallacy of composition. That fallacy is enlisted in the service of the claim that aggregate misery and not prosperity will result if all entities in society follow the classical principle of sound finance, which called for modest surpluses in normal times to provide the means to withstand occasional episodes of bad times. Within the simple-minded income-expenditure framework, if the preponderant action of private citizens was to save some of their income rather than to spend it, total income and expenditure in society would fall unless government increased its spending to offset the decline in private spending.

The fallacy of composition was a traditional piece of syllogistic logic that seemed to provide ammunition to overcome long-standing sentiments within the population that sound public budgeting was no different from sound private budgeting. Until the 1930s, the federal government normally ran modest surpluses to reduce the debt that had been accumulated during periods of war and depression. What Buchanan and Wagner (1977) called the oldtime fiscal religion died slowly between the 1930s and 1960s, but it did die. We still hear calls for restoring the old-time fiscal religion, but the clamor for restoration is now relatively quiet. Public opinion in the US seems much like that in the EU: deficits are fine so long as they are kept within manageable limits which themselves are defined in terms of the $60 \%$ and 3\% measures. Many US states, moreover, exceed the EU limits, as do many of the EU member nations.

Times have surely changed with respect to public opinion. In modern democracies, furthermore, public opinion is a significant source of political power, as such theorists from a century ago as Friedrich Wieser (1926) and Bertrand de Jouvenel (1948) explained. It is rare that democratic power manifests wearing a mailed fist. More common is the use of the velvet glove. Alexis de Tocqueville (1835) recognized the velvet glove character of democratic power in his chapter on democratic despotism in the second volume of Democracy in America.

Public opinion, it should be noted, is not reasonably assimilable to the notion of preferences in economic theory, though this situation shows signs of changing with the introduction of behaviorism into economics. Behaviorism aside, economists seem to treat preferences as private matters along the lines of Stigler and Becker (1977). This treatment follows from the model of general equilibrium which enables reduction of a society of interacting individuals to a representative agent who acts but does not interact with other people. 
Hence, preferences are data, often genetically formed data, though the Stigler-Becker formulation also provides room for preferences to be learned through practice. The key point about preferences, in any case, is their private character: they are a property of an individual and any change they undergo is through individual action, and that change is appraised as a private matter by those individuals.

Public opinion has little to do with the preferences with which economists commonly work. Public opinion resembles the Keynesian beauty contest where people are not trying to predict who will win the contest but are trying to guess how other voters will vote. This setting gives public opinion a fickle and evanescent quality in comparison to the relatively hard-wired quality that preferences have in economic theory. To be sure, such Italian theorists from a century ago as Gaetano Mosca (1947) and Vilfredo Pareto (1935) recognized this quality of public opinion in their theories about political competition. For them, in contrast to the public choice tradition of political competition initiated by Duncan Black (1958) and Anthony Downs (1957), wherein candidates sought to locate their platforms relative to relatively hard-wired voter preferences, Mosca and Pareto treated candidates as trying to frame images (Boulding 1956) of themselves that resonated with the sentiments of voters. Electoral competition was a competition among the images that candidates were able to create and was not an effort to locate some center of mass within some map of given preferences.

Frank Knight (1960) made a significant contribution to democratic budgeting in presenting his highly nuanced and much neglected treatment of knowledge and ignorance. Popular or democratic government is ruled largely by opinion, as Wieser and de Jouvenel recognize. Knight reminds us of the complex and ambiguous character of the knowledge on which popular opinion is based. In particular, Knight often remarked that it is not what we don't know that causes problems for us, but rather is what we know that is not true. Popular opinion reflects widely held belief, but such belief is not ipso facto true. In this respect, Vilfredo Pareto's (1935) distinction between logical and non-logical action is instructive.

Pareto's distinction, moreover, bears no relation to the distinction between rational and non-rational action. For Pareto, all human action is rational, in that a speaker is capable of rationalizing any action he or she undertakes, only there are different environments inside of which action manifests. Market environments place people in a setting where they sponsor experiments where they pay money to participate in the experiment, and then bear the value consequences of their actions. This setting induces responsible action by participants, which Pareto called logical action. In contrast, political environments entail mostly ideological competition without genuine experimentation because there is little possibility for people truly to select among policy proposals and then to bear the value consequences of their selection. Action inside this kind of environment was denoted as non-logical by Pareto.

\section{Budgeting: Personal vs. Democratic}

While Adam Smith averred that wise budgeting was the same for people as it was for nations, national governance was the domain of monarchs in Smith's time. Sure, Smith 
wrote toward the end of the feudal period when feudal governance based on status relationships was starting to give way to liberal governance based on contract (Maine (1864). But that period of liberal dominance lay about a century in the future when Smith wrote. For Smith, monarchy was the governing norm, and it was reasonable for people in such positions as Smith to seek to civilize the monarch by offering instruction.

To instruct a monarch, however, is not to instruct a democratic parliament. It is a category mistake to think that meaningful instruction is the same under both types of regime (Wagner 2019). A monarch is a person, and people have preferences and face choices. It is reasonable to think of someone like an Adam Smith explaining how a monarch who wanted to govern a prosperous population would be cautioned to avoid profligacy in conducting his affairs of state. The monarch might listen, or he might not, but conducting the affairs of state would reside in his bailiwick all the same. To be sure, monarchs had to be concerned with their survival in a setting where other people would have liked to possess the throne (Bueno de Mesquita 2003). Hence, the monarch faced problems of organizing his palace of the same sort that the owners of firms face in organizing their firms. Still, the monarch would face choices in undertaking action.

The monarch's situation differs from that of democratic parliaments. With democracy, governance is not reducible to some ruler's choice. To the contrary, governance entails interaction among a variety of participants, and with there being no good reason for thinking that those who participate in governance operate with something approaching consensus. Periods of near consensus might manifest from time to time, but the historical record also suggests that periods rife with antagonism can also manifest within the process of democratic governance.

The case of the renowned Italian public finance theorist Antonio de Viti de Marco is instructive in this regard. De Viti could reasonably claim to be the initiator of what became public choice with publication of de Viti (1888), where he sketched an explanatory approach to the theory of public finance, and with de Viti's approach contrasting with the hortatory approach to public finance which dominates the theory of public finance even today. De Viti's initial work was revised several times, culminating in the English translation of de Viti (1936). De Viti distinguished theoretically between cooperative and monopolistic forms of democracy. By cooperative, de Viti meant something resembling the benefit principle of public finance where the taxes people pay are reasonable facsimiles to the prices they pay through market transactions (Eusepi and Wagner 2013). De Viti's model of a cooperative state was an ideal type of construction, recognizing that reality is unlikely to conform to idealized constructions, as distinct from being a reasonable approximation in some situations.

Indeed, besides being a professor of public finance at the University of Rome, de Viti also served for 20 years as a member of the Italian parliament, elected from his home district near Lecce, and with Manuela Mosca (2016) providing a lucid summary of de Viti's life and work. De Viti's model of the monopolistic state entailed conflict among factions to secure dominance and avoid subordination. De Viti (1930) is a compilation of essays written mostly during his parliamentary years, and these essays take a ground-level orientation to- 
ward the operation of factional or monopolistic democracy by chronicling thirty years of political struggle for de Viti. Democratic budgeting is replete with winners and losers, and the task of ideology is twofold: to enable winners to feel good about their predations by enshrouding them in an ideology of public beneficence; and to sooth the feelings of losers by conveying the image that their losses were necessary to achieve a higher good.

De Viti (1858-1943) overlapped John Maynard Keynes (1883-1946). Keynes did not believe that the British government was truly democratic despite its nominally democratic form, as I noted above in discussing how Keynes believed that the conduct of government in Britain was effectively in the hands of a few wise and well-meaning people who operated through discussion and persuasion. Discussion and persuasion, moreover, was Frank Knight's (1960) vision of ideal democracy, and with discussion being distinct from the debate that often characterizes modern democracy. Discussion, it should be noted, entails participants but no audience, for the participants are the audience. In contrast, debate entails participants performing before an audience. With discussion, the objective is to reach some meeting of the minds, if this is possible; with debate, the objective is to defeat an opponent in the eyes of the audience. In this respect, de Viti (1930) calls upon his parliamentary experience to present many instances of factional domination whereby winning coalitions are able to dominate the remainder of society.

\section{A Societal Topography: action level and systems level}

Wagner (2012b), following Resnick (1994), works with a bi-planar societal architecture which has an action level and a system level. As the distinction suggests, action inside the system occurs only at the action or ground level. The system level is constructed in some fashion and is not a locus of human action. There can be many ways a portrait can be created of the system level, but however it is created it must emerge out of action that occurs at the action level. Resnick (1994) illustrates this point about distinct levels with a traffic jam. The individual cars that constitute the jam act and interact on the ground level where all action occurs. The traffic jam emerges out of interaction among those cars, and it has properties that differ from those of the cars that constitute the jam. Most significantly, time-lapse photography would show the jam to be moving backward. Yet every car in the jam moves forward slowly until it clears the jam. The jam has emergent qualities that are not carried by the individual cars but instead emerge through interaction among the cars. To be sure, the properties of systems can be changed, as illustrated for traffic by the installation of traffic lights. All the same, the properties of systems largely reflect the desires of participants as distinct from the desires of observers and planners.

Wagner (2012b) likewise distinguishes between a micro level where all actors act in economizing fashion and a macro level where no action can occur but which has real existence all the same, just as a traffic jam has real existence even though no car ever moves backward. Sure, people continually speak of doing something to change macro patterns or outcomes just as they speak of doing something to relieve traffic jams. Both levels of exis- 
tence are real, but action occurs only on the action level. Even what is described as public policy occurs at the action level. For instance, a treasury action to increase public spending by borrowing entails selling debt instruments at the action level. The macro level can be acted on only indirectly through changing patterns of action and interaction at the action level. With the relationship between micro and macro levels being emergent and not direct, the standard theory of all kinds of economic policy, including budgeting, calls for modification.

This distinction between action-level and system-level is captured by the adage: "think globally but act locally.” All action must be local in that it is attached to the ground somewhere, so to speak, in that all action is transactional. Yet action is aimed at or addressed to some global or system quality. The system level encompasses many types of constructions, projections, anticipations, hopes, and ideologies. They are portraits of systemic possibilities, as imagined in a theorist's mind or as constructed through the NIPA accounts, but they are portraits however they are fashioned. A well-meaning public official raised on the income-expenditure model might foresee a looming decline in private spending and pursue an increase in debt-financed public spending to offset that decline. Forgetting about Ricardian equivalence, debt illusion, and such matters, we may reasonably wonder how our public official will achieve this offsetting increase in public spending.

One thing we may be certain of is that he or she will not simply increase G. This is not something that can be accomplished through direct action. It can be accomplished only indirectly through local actions that end up having the projected effect. All action is local, necessarily so. An appropriation for foreign aid that transfers $\$ 1$ billion to relatively poor nations will do so through some such device as buying combines from domestic manufacturers and perhaps shipping them overseas on ships that were produced domestically. The macro-level outcome is and must be tied to some micro-level pattern of interaction that generates that macro-level pattern. This distinction between a micro-level of action and a macro-level of emergent interaction ramifies throughout the domain of political economy, public finance, and budgetary processes. I shall now illustrate this point with respect to budgeting and budgetary processes.

\section{Ricardian equivalence and budget deficits: separating truth from error}

Any consideration of public debt must start with Ricardian equivalence. Robert Barro (1974) reminds us that Keynesian-type expositions of fiscal policy have a deeply problematic feature regarding the relationship between taxation and public debt. Public debt is deferred taxation of equivalent present value to the tax that otherwise would have been imposed. When this situation is viewed within the framework of orthodox macro theory, fiscal policy vanishes as an instrument of economic policy because budget deficits can't increase aggregate spending. All budget deficits can do is induce people to decrease private consumption to create a fund to finance the higher future taxes. The debt financed increase in public spending is offset by increased private saving. Aggregate spending remains unchanged. 
Barro's framework reflects the logic of macroeconomics when the system is presumed to reflect rational action. Empirically, Ricardian equivalence has been found to tell but an incomplete story (Seater 1993). Within orthodox macro theory, the incompleteness is thought to reflect incomplete rationality within the macro system, as conveyed by notions of debt illusion where people are construed as treating the replacement of taxation with public debt as inducing them to think they are wealthier when they are not. This claim on behalf of debt illusion, moreover, resonates with the growing interest in behavioral economics in recent years with the challenges it offers to orthodox formulation of rational action.

Ignored in the controversy over deficit finance, Ricardian equivalence, and rationality in economic action, however, is recognition that the macro level is inert in that is not and cannot be a direct locus of action. The macro level cannot be acted on directly because all action occurs on the micro level. How micro-level action projects to the macro level, moreover, is a complex matter that depends on patterns of interaction among entities throughout the micro-level of action. Figure 1, first used in Wagner (2012b: 437), illustrates the point.

Figure 1. Aggregate Variables within an Ecology of Plans

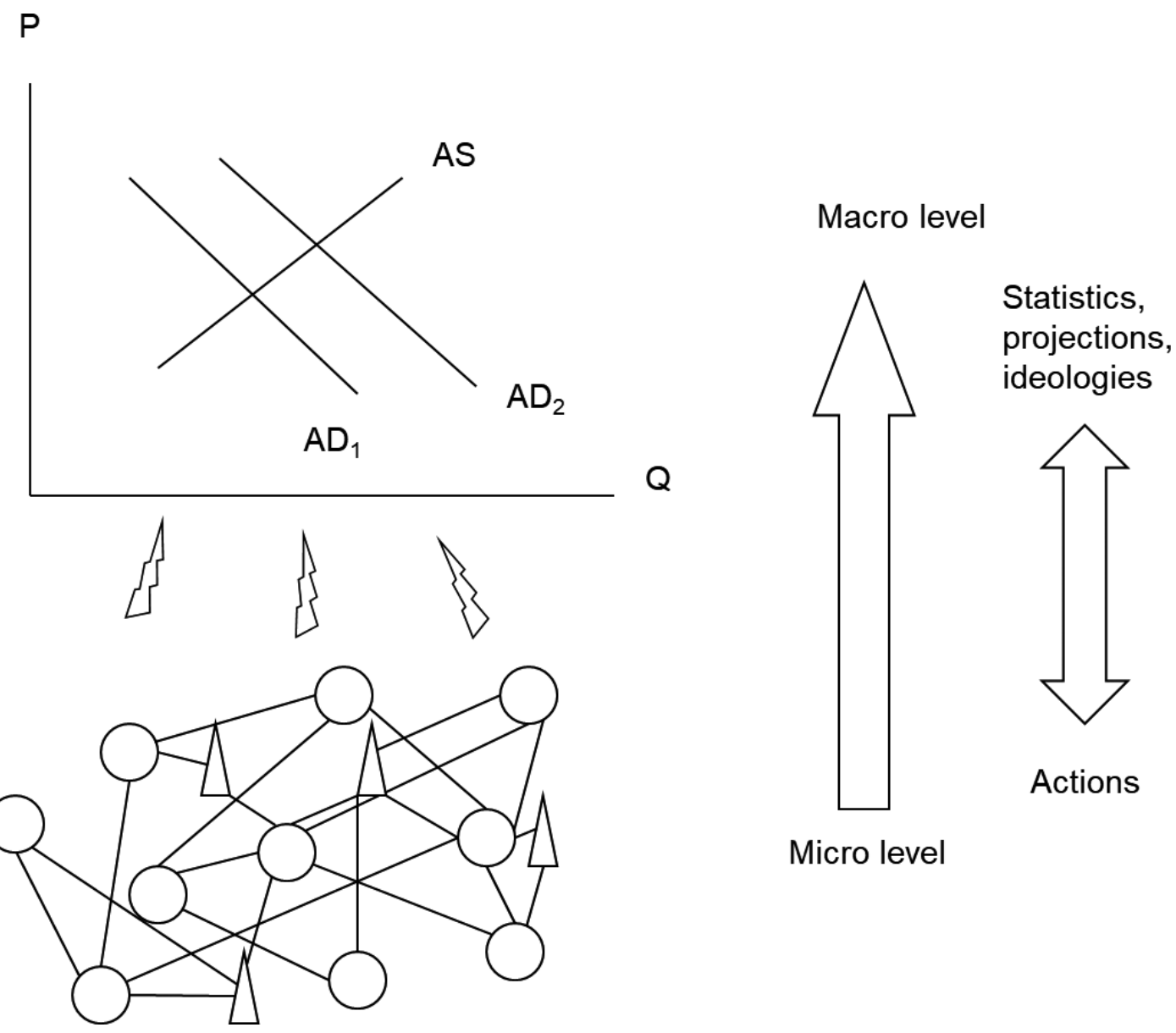


There, the macro level is conveyed by the AS-AD model. Macro observations are generated through interactions at the micro level of action. This level is described by a combination of circles and triangles to denote that the micro economy contains a combination of politically-based and market-based entities.

Any so-called policy action must start somewhere on the micro level. Eventually, that action will project onto the macro level, but just how that projection occurs will depend on the pattern of interaction among the entities that interact on the micro-level. There is no good reason to assume that all those interactions are reducible to that of some representative agent or interaction. To the contrary, we may reasonably anticipate that people will differ in how they react. Suppose the policy action in question is a debt-financed increase in public spending. In standard macro theory, that increase in spending would be represented by an increase in aggregate demand. In contrast, the arithmetic of Ricardian equivalence would hold that aggregate demand was unchanged because the increase in political demand was offset by a decrease in private demand.

All such formulations treat as factual the ability of economic actors to affect systemic outcomes without constructing some pattern of micro-level action and interaction that will generate that outcome. Suppose, instead, that we try to do so along the lines of the constructivist methodology that Joshua Epstein (2006) sets forth. Older expositions of fiscal policy require some identifiable government agency to increase its spending on real activities, which occurs at one of the triangles in Figure 1. The means to do that, moreover, come from the Treasury which places an issue of bonds with some brokerage house, represented by a circle in Figure 1. This operation will project as an increase in aggregate demand by the standard exposition of fiscal policy. What is especially notable, however, is that different points of injection for the increased spending will create different patterns of gain within the economy, even if they all yield the same increase in aggregate demand. What happens, then, is a micro-theoretic and not a macro-theoretic matter. Public debt may have no effect on net worth in the aggregate and yet it can redistribute wealth within the society, depending both on the way spending is increased and the way that future taxes are likely to be imposed.

Contemporary references to quantitative easing change this analysis not one bit. References to the macro-level miss the process that generates the observations. Any increase in aggregate demand, should this be the outcome of the program, is a secondary outcome of the program. This recognition means that standard, macro-theoretic depictions of public policy constitute a form of shell game. A shell game operates by misdirecting the observer's attention. Macro-oriented discussions of budgeting misdirect the spectator's attention from what is really happening, just as happens with a shell game. The macro scheme of thought converts all individuals into averages with pro rata shares of any claimed societal outcome, as illustrated by representative agent modeling. Hidden from view in this scheme of thought is recognition that any policy action entails a choice between options (Buchanan 1969), and with those options conferring different patterns of gain and loss within the population. One of the particularly notable illustrations of the macro policy shell game is the common claim that internally-held public debt is something we owe to ourselves, the falsity of which $\mathrm{Bu}-$ 
chanan (1958) set forth. This claim is a piece of ideology that erases any distinction between winners and losers from policy operations.

\section{Budgeting with the state as financial intermediary}

When it comes to democratic budgeting, we must grapple with recognition that the state is not an acting entity that trades on its own account (Eusepi and Wagner 2017). If the state borrows, legislators do not become indebted. The state is but an intermediary that stands between people who have programs for which they seek support and people who have the means to support those programs but who often would rather not do so. With respect to budgeting and deficit finance, let me illustrate the situation with a simple comparison of two alternative institutional arrangements.

Consider a town with 10,000 people that finances its activities with an equal per capita charge imposed on everyone. Let us assume that this charge is $\$ 1,000$ annually, a portion of which goes for maintenance of an earthen dam that provides water for drinking, irrigation, and recreation. A rare earthquake created cracks in the dam which a team of engineers asserts would only worsen until the dam burst. To replace the dam with one made of steel and concrete would require a one-time charge of $\$ 5,000$ on each resident. Rather than sending each resident a tax bill for $\$ 5,000$, the town could borrow $\$ 50$ million and amortize that debt by increasing future tax assessments. If this were done, a single public debt of $\$ 50$ million would replace whatever set of personal debt residents would have incurred in response to this special tax assessment. We may reasonably expect that people would differ in how they respond to this situation. Some might discharge this assessment immediately, others might borrow the entire $\$ 5,000$, and still others might borrow part of the assessment. In any case, there would be no public debt. Instead, some people would be indebted to others.

It is a category mistake, however, to treat the town as truly indebted. The monarchs of old could become indebted to other nobles from whom they might borrow on occasion. In this case, there was an identifiable entity who traded on his own account. With democracies, however, there is no individual who trades on his or her own account. A town council might decide to issue debt to finance the dam rather than leaving it up to individual citizens to determine how they will cover their personal tax assessments. The members of the town council, however, do not trade on their personal accounts. They do not become indebted, other than for their pro rata share of the expense of the dam. The town council is merely a financial intermediary that oversees a network of borrowing and lending within the town, replacing the private financial transaction that would otherwise have resulted.

Ricardian equivalence surely leads thought astray, as does any shell game, in thinking about governments as financial intermediaries with respect to public debt. With market-based financial intermediation, all participants trade on their own accounts. We can imagine a distribution of indebtedness within the town to finance the dam. Some people might have borrowed $\$ 5,000$, others $\$ 4,000$, and so on, with many borrowing nothing and paying their tax currently. Furthermore, with internal debt some of those residents would 
have been lenders who paid the current tax bills for the borrowing residents. Democratic debt disguises the pattern of obligations that public debt entails, opening the way for factional politics to displace the neutrality that Ricardian equivalence projects.

We can well imagine a setting where public debt is accompanied by an assignment of a pattern of explicit liabilities for future payment (Wagner 1986). In this case what is described as public debt would be just an aggregation of the personal liabilities for repayment that had been assigned within the population. Suppose the town borrows the entire $\$ 50$ million, but assigns $\$ 5,000$ liabilities to each of the residents, and with those residents accepting those assignments just as surely as they agreed to other forms of personal debt. Those liabilities would remain with the residents even if they moved out of the town and would be incorporated into their estates should they die. Such liabilities would thus be like ordinary consumer and commercial debt. In other words, liability for repayment of public debt would be assigned at the time the debt was created, in contrast to the present situation where it is left hanging as a liability to be assigned in the future.

True, cases of insolvency would arise in this situation, creating issues regarding who bears the burden of insolvency. With ordinary commercial transactions, that burden rests on the lender which in turn renders lenders cautious in extending loans. With public debt, by contrast, one borrower's insolvency is met by increasing the liability on other borrowers. With lenders thus facing a lower risk from borrower insolvency, public debt transactions understandably carry lower rates of interest than personal debt transactions. This lower rate of interest, however, does not represent a form of what might be called social saving. It is not that government is a lower risk borrower, for to say this is to treat democratic legislatures as if they were monarchs. To the contrary, the lower rate of interest charged on public loans reflects a lower risk to lenders, yes, but only because the risk of personal default is shifted onto other taxpayers. Public debt operations redistribute risk but do not reduce it. The lower rate of interest on public loans is another manifestation of the macro shell game.

\section{Voice, Exit, and the Control of Faction}

Budget deficits emerge out of a fiscal process that enables winners to shift costs onto others. If we assume that our town's dam is desired more strongly by some people than by others, borrowing can increase support relative to what would happen if tax liabilities were assigned at the time the project was approved. For this outcome to happen, it must be the case that the option of borrowing lowers the cost of supporting the dam for some people. One simple way to illustrate this possibility is to start from a position where the population is roughly evenly divided between repairing the earthen dame, recognizing that this repair will last only a few years, and replacing that dam with one made of steel and concrete. This even division pertains to an institutional setting where all liabilities are assigned to individual residents, so the town itself is not involved in the pattern of debts and loans that stem from the dam.

What must be the case if introduction of the option of public debt increases support for 
the dam? Obviously, it must be that more people must regard public debt as beneficial than regard it as harmful. Replacement of a set of private loans with a public loan reduces the rate of interest charged for those loans. On this account alone, public debt would seem to increase support for the project. This lower interest rate is commonly interpreted as representing the position of government as a lower cost borrower. While accurate, this statement is also misleading because there is no identifiable entity that becomes indebted with the public loan. The town does not become indebted but rather merely intermediates among the residents. However, that intermediation is not performed explicitly but is folded into the budgetary process where any explicit assignment of liabilities is lost from view.

In an earlier age when frugality was thought to be a quality of good government, we might well imagine some predilection against deficit finance in normal times, as characterized the United States prior to the 1930s. Once public opinion changes in the direction of thinking that budget deficits can also serve as a tool of economic management, a democratic polity takes on a different default setting with respect to presumptions about good budgeting. Previously, debt was regarded negatively. Now it is regarded neutrally or even positively. Either way, there is a reduction in any reluctance to engage in deficit finance.

Debt finance lowers the perceived cost of government in two distinct ways. One way entails some lowering of tax burdens for some people. When liabilities are not assigned personally, the perceived cost of collective activity falls for those who lack infinite horizons, recognizing that personal liability forces an infinite horizon outlook on people. The older someone is, ceteris paribus, the lower the perceived cost of public activity. The higher the prospect of personal mobility, the lower will be that perceived cost. Are there institutional means of creating a more accurate appraisal of cost? There are, and the key resides in exploring how personal liability forces people to act as if they have infinite horizons. Under personal liability, someone who leaves town or dies does not escape liability. The debt remains with the person despite moving elsewhere, and it transfers to the estate upon death. The analysis of debt under personal liability works as if people operated with infinite horizons, which means in turn that borrowing does not entail a perceived lower cost than taxation. Without personal liability, debt will reduce perceived cost for some people while increasing it for no one.

The second way that public debt increases support for government spending is by its ability to create an organized interest group in support of higher spending. When government is financed under a balanced budget, we can think of people as evaluating governmental programs in two respects: as payers of tax and as beneficiaries of services. Suppose we divide the population into three groups. One group we can call neutrals. These would be people whose marginal valuations of taxing and spending are equal. Net taxpayers would be people who regarded the services they received as not worthwhile relative to their tax payments. Net beneficiaries would be in the opposite position, perceiving their benefits as well worth their tax payments.

If we suppose that neutrals abstain from voting, whether a project is undertaken with debt financing depends on the relative sizes of the net taxpayers and net beneficiaries, with 
debt bring pursued if net beneficiaries outnumber net taxpayers. Left out of this simple numerical account is recognition of how public debt transforms a subset of net taxpayers into acting as though they were net beneficiaries. Public debt creates a subset of taxpayers who have a special interest in public spending because public spending is the means by which they are compensated for their effective payment of taxes for those taxpayers who deferred their payments by supporting public debt. Once we move into the world of factional politics, it becomes useful to distinguish between willing debtors and forced debtors. Willing debtors are those people who would have supported the expenditure program under taxation and supported it more strongly when it was financed by debt. Forced debtors would not have supported the program under tax finance and are forced to bear a burden of debt repayment all the same.

Consider Albert Hirschman's (1970) distinction between exit and voice as ways of influencing the performance of organizations. Hirschman treated these methods as additive and, moreover, sought to bring increased attention to voice over exit. All the same, there is surely merit in thinking of the two as interactive. Voice is necessary to learn about the sources of organizational weakness. But exit is necessary if voice is to do its work because voice without an exit option lacks muscle.

As we move up the ladder of levels of government in the United States, we move from a situation where exit is easy to one where it is hard. Exit is relatively easy in small cities and towns. Exit is perhaps less easy at the level of states, but the option is still there. At the national level, however, exit is relatively difficult. What does the easiness or difficulty of exit have to do with public debt? When exit is relatively easy, democratic polities will tend to operate in consensual fashion, as represented by the benefit principle of public finance. What leads to this mode of operation is the need for the supporters of political programs to attract taxpayers to their jurisdictions. With exit, jurisdictions must attract residents who are able to locate in other jurisdictions. The political process is roughly constrained to follow something like the benefit principle not so much out of intention as out of necessity.

It is at the national level of government where exit becomes relatively costly, and which renders voice in turn an instance of cheap talk and not influential or effective talk. Where exit is easy, political exchanges are mostly dyadic relationships that capture mutual gains. When exit is costly, political exchanges still operate because the world of democratic political economy is constructed through transactions. With costly exit, however, those transactions take on triadic character (Podemska-Mikluch and Wagner 2013). With triadic exchanges, there are both winners and losers in any transaction. The winners receive a net gain from the transaction; the losers lose at the margin of decision by paying more in tax than however much they value the service. With respect to the town and its dam, the winners are net beneficiaries while the losers are net taxpayers. For triadic transactions, it is the ability of the transactional web to incorporate people who would veto the fiscal operation if they had the ability to do so that provides the cost reductions for those who support the project in question, as Levine and Plott (1977) and Plott and Levine (1978) explain cogently. 


\section{Some Closing Remarks on Democratic Budgeting}

Ricardian equivalence holds that public debt is just deferred taxation, and with the present value of that deferred taxation being equivalent to the current taxation that otherwise would have been imposed. Public debt alters the timing of nominal tax payments, but that is all it does according to Ricardian equivalence. Yet Ricardian equivalence is an incomplete and even misleading scheme of analysis because it reduces a society to a single individual, therefore avoiding all phenomena that stem from differences among people. Public debt is more than a deferment of taxation. It also undermines the principles of contract that is the basis of trust in society (Wagner 2017). Ordinary debts follow the contractual logic of promise and commitment (Fried 1981). A borrower promises to repay a debt and the lender relies on that promise. Through such private law arrangements, trust builds through experience in societies governed by private law principles.

This situation can change when public law comes into play. Besides a public debt that exceeds \$20 trillion, the United States federal government has an implicit debt in the form of unfunded liabilities that exceed $\$ 100$ trillion by some estimates. Suppose you put unfunded liabilities into the contractual language of promise and commitment. An unfunded liability means that the promises that have been made to beneficiaries exceed the commitments that have been made to taxpayers by something on the order of $\$ 100$ trillion. This situation surely qualifies as a form of systemic lying. Public debt corrupts the practice of contract to the extent that promises regarding the future do not vest in the present sponsors who make those promises. With the monarchs of old, their promises to repay creditors in the future vested with the monarchs. By contrast, there is no such vesting with democratic public debt, though there could be if liability for future payments were assigned at the time the debt was created. To be sure, if politicians had to assign those future liabilities now, they would surely be less eager to resort to public debt, which in turn would surely lower their desires to spend.

\section{References}

Barro, R.J. (1974). Are government bonds net wealth? Journal of Political Economy 82: 1095-1118.

Black, D. (1958). Theory of Committees and Elections. Cambridge: Cambridge University Press.

Boulding, K.E. 1956. The Image: Knowledge in Life and Society. Ann Arbor: University of Michigan Press.

Buchanan, J.M. (1958). Public Principles of Public Debt. Homewood, IL: Richard D. Irwin.

Buchanan, J.M. (1969). Cost and Choice. Chicago: Markham.

Buchanan, J.M. and Wagner, R.E. (1977). Democracy in Deficit: The Political Legacy of Lord Keynes. New York: Academic Press.

Bueno de Mesquita, B. et al. 2003. The Logic of Political Survival. Cambridge, MA: MIT 
Press.

De Jouvenel, B. (1948). On Power: Its Nature and the History of its Growth. London: Hutchinson.

De Jouvenel, B. (1961). The chairman's problem. American Political Science Review 55: 368-72.

De Tocqueville, A. (1835 [2002]. Democracy in America. Chicago: University of Chicago Press.

De Viti de Marco, A. 1888. Il carattere teorico dell'economia finanziaria. Rome: Pasqualucci.

De Viti de Marco, A. 1930. Un trentennio di lotte politiche. Roma: Collezione Meridionale Editrice.

De Viti de March, A. 1936. First Principles of Public Finance. London: Jonathan Cape.

Downs, A. 1957. An Economic Theory of Democracy. New York: Harper \& Row.

Epstein, J.M., ed. 2006. Generative Social Science. Princeton, NJ: Princeton University Press.

Eusepi, G. and Wagner, R.E. (2013). Tax prices in a democratic polity: The continuing relevance of Antonio de Viti de Marco. History of Political Economy 45: 99-121.

Eusepi, G. and Wagner, R.E. (2017). Public Debt: An Illusion of Democratic Political Economy. Cheltenham, UK: Edward Elgar.

Fried, C. (1981). Contract as Promise: A Theory of Contractual Obligation. Cambridge, MA: Harvard University Press.

Garvey, G. 1975. Keynes and the economic activists of pre-Hitler Germany. Journal of Political Economy 83: 391-405

Harrod, R.F. (1951). The Life of John Maynard Keynes. London: Macmillan.

Hirschman, A. (1970). Exit, Voice, and Loyalty. Cambridge, MA: Harvard University Press.

Knight, F.H. (1960). Intelligence and Democratic Action. Cambridge, MA: Harvard University Press.

Keynes, J.M. 1936. The General Theory of Employment, Interest, and Money. New York: Harcourt Brace.

Levine, M.E. and Plott, C.R. 1977. Agenda influence and its implications. Virginia Law Review 63: 561-604.

Maine, H. 1864. Ancient Law, $5^{\text {th }}$ ed. New York: Henry Holt.

Meadows, D.H. 2008. Thinking in Systems: A Primer. White River Junction, VT: Chelsea Green.

Miller, J.C.III. 1994. Fix the US Budget! Urgings of an Abominable No-Man. Stanford, CA: Hoover Institution Press.

Mosca, G. (1947). Elementi di scienza politica, $4^{\text {th }}$ ed. Bari: G. Laterza.

Mosca, M. 2016. Antonio de Viti de Marco: a story worth remembering. Basingstoke, UK: Palgrave Macmillan.

Ostrom, V. 1984. Why governments fail: an inquiry into the use of instruments of evil to do good. In J.M. Buchanan and R.D. Tollison, eds., Theory of Public Choice II (Ann Arbor: University of Michigan Press), pp. 422-35. 
Ostrom, V. 1996. Faustian bargains. Constitutional Political Economy 7: 303-08.

Pareto, V. (1935 [1915]). The Mind and Society. New York: Harcourt Brace.

Plott, C.R. and Levine, M.E. (1978). A model of agenda influence on committee decisions. American Economic Review 68: 146-60.

Podemska-Mikluch, M. and Wagner, R.E. 2013. Dyads, triads, and the theory of exchange. Review of Austrian Economics 26: 171-82.

Primo, D. 2007. Rules and Restraint: Government Spending and the Design of Institutions. Chicago: University of Chicago Press.

Resnick, M. (1994). Turtles, Termites, and Traffic Jams. Cambridge, MA: MIT Press.

Seater, J.J. 1993. Ricardian equivalence. Journal of Economic Literature 31: 142-90.

Stigler, G.J. and Becker, G.S. (1977). De gustibus non est disputandum. American Economic Review 67: 76-90.

Wagner, R.E. (1986). Liability rules, fiscal institutions, and the debt. In C.K. Rowley and R.D. Tollison, eds. Deficits. Oxford: Oxford University Press, pp. 374-90.

Wagner, R.E. (2012a). Deficits, Debt, and Democracy: Wrestling with Tragedy on the Fiscal Commons. Cheltenham, UK: Edward Elgar.

Wagner, R.E. (2012b). A macro economy as an ecology of plans. Journal of Economic Behavior and Organization 82: 433-44.

Wagner, R.E. (2017). Public Debt and the Corruption of Contract; published simultaneously as Il debito pubblico e la corruzione delle promesee. Milan: Bruno Leoni Institute.

Wagner, R.E. 2019. Public Debt as a Form of Public Finance: Overcoming a Category Mistake and its Vices. Cambridge: Cambridge University Press.

Wieser, F. (1926). Das Gesetz der Macht. Vienna: Julius Springer.

Wilson, W. 1885. Congressional Government. Boston, MA: Houghton Mifflin. 